
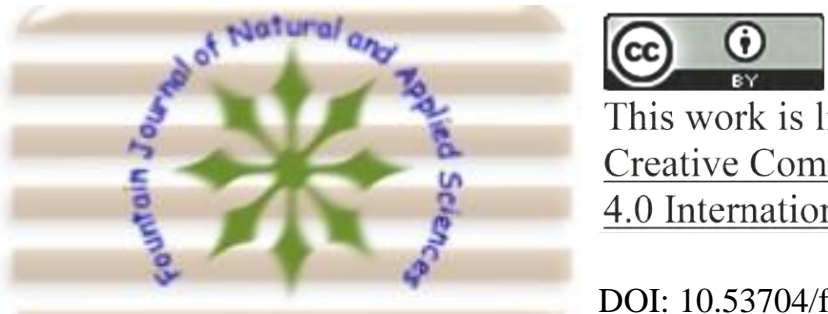

This work is licensed under

Creative Commons Attribution

4.0 International License.

DOI: 10.53704/fujnas.v10i1.334

A publication of College of Natural and Applied Sciences, Fountain University, Osogbo, Nigeria.

Journal homepage: www.fountainjournals.com

ISSN: 2354-337X(Online),2350-1863(Print)

\title{
Optimization of Conditions for Xylanase Production Using Aspergillus tubingensis Under Different Carbon Sources
}

\author{
${ }^{* 1}$ Kolade, I. O., ${ }^{1}$ Yousuf, M. B., ${ }^{2}$ Ajijolakewu, K. A., ${ }^{2}$ Agbabiaka, T., ${ }^{2}$ Abdulkareem, T. Z. and \\ ${ }^{2}$ Faniyi, I. O. \\ ${ }^{I}$ Department of Animal Production, Faculty of Agriculture, University of Ilorin, Nigeria \\ ${ }^{2}$ Department of Microbiology, Faculty of Life Sciences, University of Ilorin, Nigeria
}

\begin{abstract}
Xylanases are hydrolytic enzymes with wide range of applications in food processing, bleaching of pulp in paper manufacturing industry, bio-conversion of biomass wastes to fermentable sugars and enhancing nutrient digestibility in animal feeds. The optimization of growth conditions and evaluation of an appropriate substrate as carbon source among cassava peels, corn cobs, wheat bran and rice husk on xylanase production by novel strain of Aspergillus tubingensis under Solid State Fermentation (SSF) was investigated. The fungal isolate was identified based on ribosomal RNA gene and ITS gene sequencing analysis as Aspergillus tubingensis. Results showed that Corn cobs had the highest xylanase production among the four substrates. Corn cobs recorded the highest value of xylanase production at $\mathrm{pH}$ of 6.0 $(107.97 \mathrm{U} / \mathrm{g})$, after incubation period of 72 hour $(111.23 \mathrm{U} / \mathrm{g})$, at temperature of $30^{\circ} \mathrm{C}(44.26 \mathrm{U} / \mathrm{g})$ and at ratio $1: 3(45.68 \mathrm{U} / \mathrm{g})$. The optimum growth conditions for xylanase production by Aspergillus tubingensis were: $\mathrm{pH} 6.0$, incubation period of 72 hours, temperature of $30^{\circ} \mathrm{C}$ and substrate concentration of $1: 3(4 \mathrm{~g}$ of substrate per $12 \mathrm{ml}$ of fermentation medium). Corn cobs showed the highest yield of xylanase activity $(111.23 \pm 0.31 \mathrm{U} / \mathrm{g})$, followed by Rice husk $(101.91 \pm 0.72 \mathrm{U} / \mathrm{g})$, Wheat bran $(89.30 \pm 1.16 \mathrm{U} / \mathrm{g})$ and Cassava peel $(87.03 \pm 0.57 \mathrm{U} / \mathrm{g})$. In conclusion, among the various agro residues that were used as carbon sources, Corn cobs had maximum xylanase activity. Various culture conditions were optimized by using one factor at a time method and the maximum xylanase production was obtained at $\mathrm{pH}$ of 6.0, incubation period of 72 hour, temperature of $30^{\circ} \mathrm{C}$ and substrate concentration of $1: 3$ under solid state fermentation. It is therefore suggested that some other notable environmental and fermentation factors that influence metabolism-mediated production yields of xylanase like aeration, agitation, carbon and nitrogen sources, metal ion requirement, inoculum size etc. should be optimized for maximum production of enzyme.
\end{abstract}

Keywords: Solid State Fermentation, Cassava peels, Corn cobs, Wheat bran, Rice husk

\section{Introduction}

The need for continuous use of cheap and locally available crop residues and agro-industrial byproducts is a necessity to commercialize agrowastes, reduction in environmental pollution and improve employment generation in Africa like Nigeria and Asia. The use of abundantly available low cost agricultural residue as carbon sources

*Corresponding author: +234706663908

Email address: koladeishaq@gmail.com 
conditions could be used to decrease cost of xylanase production. Such carbon sources include wheat bran, cassava peel, corn cobs and rice husk. This can be achieved by optimizing the fermentation media (Shah \& Madamwar, 2005). Optimization is a process to determine the best cultural and nutritional conditions that significantly influence the yield of xylanases. Apart from the properties of organism, xylanase production is affected by environmental conditions of $\mathrm{pH}$, temperature, initial moisture, inoculum size, period of incubation and the nutritive components of the growth medium (Uday et al., 2016). Optimization of media composition is vital to improve both the productivity and the activity of enzymes like xylanases using one-factor-at-a-time (OFAT) method (Ajijolakewu et al., 2017). This study was therefore conducted to determine the optimum growth conditions for $A$. tubingensis and to select an appropriate substrate as carbon source among cassava peels, corn cobs, wheat bran, and rice husk for efficient production of xylanase using solid state fermentation.

\section{Materials and Methods Chemicals}

All chemicals and reagents used were of analytical grades and are from Sigma (St. Louis, MO USA) or Merck (Darmstadt, Germany)

\section{Microorganism}

\section{Isolation and Identification of Xylanolytic Microorganism}

The soil samples for the isolation of xylanolytic microorganisms were collected from different areas of agricultural field at the premises of the Nigerian Stored Products Research Institute (NSPRI), km 3, Asa Dam road, Ilorin, Kwara state, Nigeria. The isolation of fungi was carried out on potato dextrose agar (PDA) using the samples obtained from agricultural soils, decaying woods, and agricultural waste materials. One gram of soil sample was suspended in $10 \mathrm{~mL}$ of sterile distilled water and shake vigorously for $10 \mathrm{~min}$. Thereafter, $1.0 \mathrm{~mL}$ of the resulting liquid was spread on the surface of PDA using an L-shaped glass rod and incubated at $37^{\circ} \mathrm{C}$ for 6 days. The fungal isolate formed was subcultured to purify it and examined for xylanolytic activities. Screening for xylanolytic activities was performed on malt extract agar (MEA) containing $0.1 \%(w / v)$ of xylan from beech wood. Positive xylanolytic isolate was detected according to the clear zones of hydrolysis on the xylan. The potential isolates were subcultured and maintained on MEA slants. The slants were stored at $4^{\circ} \mathrm{C}$ prior to use. The selected isolate was identified by cultural techniques and verified by molecular identification using partial 18S rRNA, ITS1, 5.8S rRNA, ITS2 and partial 28S rRNA gene sequencing at IITA, Ibadan, Nigeria. The potential isolate, Aspergillus tubingensis, was grown (subculture) on potato dextrose agar (PDA) medium at $30^{\circ} \mathrm{C}$ for 4 days and stored at $4{ }^{\circ} \mathrm{C}$ on PDA slant.

\section{Inoculum Development}

Ten milliliters $(10 \mathrm{~mL})$ of $1 \%$ Tween-80-sterile distilled water was added to 4-day old pure culture on agar plate to obtain spore suspensions. Suspensions were sieved through $0.5 \mathrm{~mm}$ filter to remove mycelia. With appropriate dilutions, inoculum sizes (spores/mL) were determined by direct microscopic observation using haemocytometer (Aberkane et al., 2002; Rodriguez-Tudela et al., 2003).

\section{Substrates}

Four different agro-industrial by-products and crop residues namely corncob, wheat bran, cassava peel and rice husk were used as carbon sources for the optimization of growth condition for enzyme production. Rice husk was procured locally from rice milling industry at Sango, Ilorin, Kwara State. Corn cobs were collected after harvesting the corn on the field at Teaching and Research Farm, University of Ilorin, Nigeria. Wheat bran was obtained at T and K Agro-Allied Enterprises, FateTanke road, Ilorin, Kwara State. Cassava peel was sourced locally at Gari processing industry, Sango, Ilorin, Kwara State. The four substrates were dried in the oven at $80^{\circ} \mathrm{C}$ for $2 \mathrm{~h}$, ground, and passed through a sieve $(0.5 \mathrm{~mm}$ pore size $)$ to obtain the fine powder used for the study.

\section{Optimization of growth conditions}

Physiochemical parameters such as substrate concentration, inoculum size, $\mathrm{pH}$, incubation 
period, and temperature may affect the enzyme production. Hence, there is need to find the optimum fermentation conditions for maximum production of xylanase. One-factor-at-a-time (OFAT) approach was employed to evaluate the optimal fermentation conditions for xylanase production by solid-state fermentation using Aspergillus tubingensis. This was carried out by varying the four (4) physiochemical parameters like $\mathrm{pH}$, substrate concentration, temperature and incubation period.

i.Effect of pH: The effect of initial hydrogen ion concentration $(\mathrm{pH})$ on enzyme production was assessed for optimization by adjusting the initial $\mathrm{pH}$ of production medium at 4.0, 5.0, 6.0, 7.0, 8.0, 9.0 and 10.0 with $1 \mathrm{M} \mathrm{NaOH}$ and $1 \%$ sulphuric acid.

ii. Effect of Incubation Period: To optimize incubation period for xylanase production, Erlenmeyer flasks $(250 \mathrm{~mL})$ containing four gram (4g) of each of the four substrates were prepared. Samples were harvested for a period of 24, 48, 72, 96 and 120 hours while keeping the other fermentation conditions constant.

iii. Effect of Temperature: Effect of incubation temperature on xylanase production was studied by incubating the inoculated flasks at different temperatures ranging from 25 , to $50^{\circ} \mathrm{C}$ at intervals of $5{ }^{\circ} \mathrm{C}$ while keeping the other fermentation conditions constant.

\section{iv. Effect of Substrate concentration:} Substrate concentration is an important factor at SSF. It has a lot of influences on other culture fermentation factors. Substrate concentration was assessed for optimum xylanase production by varying the ratio of substrate $(\mathrm{g})$ to fermentation medium $(\mathrm{mL})$ at 1:1, 1:2, 1:3, 1:4 and 1:5 $(\mathrm{g} / \mathrm{mL})$. The effect of different substrates (Rice husk, Cassava peel, Corncob and Wheat bran) were studied at different concentrations at ratio $1: 1,1: 2$, 1:3, 1:4 and 1:5 (4g: $4 \mathrm{~mL}, 4 \mathrm{~g}: 8 \mathrm{~mL}, 4 \mathrm{~g}: 12 \mathrm{~mL}$, 4g:16mL and $4 \mathrm{~g}: 20 \mathrm{~mL}$ ) respectively during fermentation process for a period of 72 hours.

Production of Xylanase by Solid State Fermentation
Xylanase biosynthesis was carried out in $250 \mathrm{~mL}$ conical flasks using SSF in a production medium containing $12 \mathrm{~mL}$ mineral salt medium. Four gram (4g) of each of the four (4) substrates (corncob, wheat bran, rice husk and cassava peel) were added to each flask and kept. Substrates were moistened with $12 \mathrm{~mL}$ of mineral salt medium. Composition of the growth medium includes $(\mathrm{g} / \mathrm{l})$ : yeast extract (2.5), $\mathrm{K}_{2} \mathrm{HPO}_{4}$ (2), $\mathrm{CaCl}_{2}(0.4), \mathrm{CaCO}_{3}$ (0.001), $\mathrm{CuSO}_{4}$ (0.002), Tween-80 (2), $\mathrm{MgSO}_{4}(0.3), \mathrm{FeSO}_{4}$ (0.005), MnSO4 (0.002), $\mathrm{ZnSO}_{4} .7 \mathrm{H}_{2} \mathrm{O}$ (0.0014), $\mathrm{CoCl}_{2}$ (0.002), $\mathrm{NaCl}_{2}$ (0.002). They were autoclaved at $121^{\circ} \mathrm{C}$ for $30 \mathrm{~min}$, cooled and inoculated with $1 \mathrm{~mL}$ of standardized inoculums (2 $\mathrm{x} 10^{6}$ spores/ $\mathrm{mL}$ ) into the medium and the fermentation was allowed to proceed at $30^{\circ} \mathrm{C}$ for 5 days. Each Experiment was carried out in triplicate.

\section{Xylanase production on various lignocellulosic substrates}

The fungal isolate Aspergillus tubingensis was grown in $250 \mathrm{~mL}$ conical flasks containing $4 \mathrm{~g}$ each of various lignocellulosic substrates (corn cob, wheat bran, rice husk, and cassava peel) and moistened with MS medium. The enzyme was extracted and assayed.

\section{Crude Enzyme Extraction}

The enzyme from the substrates was extracted separately using $0.05 \mathrm{M}$ citrate buffer ( $\mathrm{pH} 4.8$ ). Following the addition of buffer, the whole flask was kept in a rotary incubator at $180 \mathrm{rpm}\left(30^{\circ} \mathrm{C}\right)$ for 15 minutes and squeezed through muslin cloth to extract the crude enzyme. The enzyme extract obtained was centrifuged at $10,000 \mathrm{rpm}$ at $4^{\circ} \mathrm{C}$ for $15 \mathrm{~min}$. The clear supernatant obtained was used as the enzyme sample for assay.

\section{Enzyme Assay}

Xylanase activity is most commonly determined by measuring the release of reducing sugars from prepared xylan, such as oat spelt, Birchwood or Beachwood xylan. Xylanase activity (IU/g) was determined quantitatively by DNSA Method (Bailey et al., 1992) using 1\% xylan (w/v) from beechwood (Sigma, USA) as substrate. One unit of xylanase is defined as the amount of enzyme that liberates $1 \mu \mathrm{mol}$ reducing sugar as 
xylose $/ \mathrm{mL} / \mathrm{min}$ under the assay condition. The reducing sugars produced were quantified by the dinitrosalicyclic acid method using D-xylose as standard. $0.2 \mathrm{~mL}$ of suitably diluted crude enzyme (culture filtrate) was added to $1.8 \mathrm{~mL}$ of xylan solution $1 \%$ beech wood xylan in test tube placed in water bath at $50^{\circ} \mathrm{C}$ for 5 minute as described by (Bailey et al., 1992). The reaction was stopped by adding $3 \mathrm{~mL}$ DNS (3, 5 dinitrosalicylic acid) reagent and kept the tubes in boiling water $\left(100^{\circ} \mathrm{C}\right)$ for $5 \mathrm{~min}$. The tubes were allowed to cool and the reducing sugars liberated were measured (absorbance) at 540nm wavelength with spectrophotometer (Spectronic Genesys TMS, USA) against appropriate blank. The amount of xylose liberated was calculated with the standard curve of xylose as described by (Ajijolakewu et al., 2016).

\section{Xylan Substrate Solution (1\%)}

One gram of beech wood xylan was weighed and dissolved in $100 \mathrm{~mL}$ of distilled water. It was stored in an air-tight container and preserved in the refrigerator prior to usage.

\section{Xylose Standard}

This was prepared by accurately weighing $0.15 \mathrm{~g}$ of xylose and dissolved in $100 \mathrm{~mL}$ of citrate buffer. Dilutions were made from the stock solution prepared (Bailey et al., 1992).

\section{Standard Curve for Xylose}

Different concentrations (2.0, 3.3, 5.0, 6.7, 10 $\mu \mathrm{mol} / \mathrm{mL}$ ) of Xylose were prepared in distilled water. $0.5 \mathrm{~mL}$ of each concentration was added in test tubes along with $0.5 \mathrm{~mL}$ of DNS solutions.
These test tubes were boiled for 5 minutes in boiling water and then cooled. A blank was also prepared by dissolving $1 \mathrm{~mL}$ each of DNS and distilled water. Absorbance of these solutions was determined by using a spectrophotometer at 540 nm. A graph was drawn by plotting concentration against absorbance.

\section{Xylanolytic Activity}

Xylanase activity is measured by determining the release of reducing sugars from prepared beechwood xylan. Measurement of enzyme activity was carried out under conditions closely defined with respect to temperature, $\mathrm{pH}$, substrate concentration and substrate type, since all these factors affect the activity of enzyme (Beauchemin et al., 1999). Effects of enzyme on sugar correspond to the level of xylanolytic activities on the degradability of substrate (lignocelluloses) and it is measured by absorbance using spectrophotometer.

\section{Statistical Analysis}

All the experiments were carried in triplicates and the data represents the mean value of three replicates. Statistical differences of generated data was determined by one-way Analysis of Variance $(\alpha=0.05)$ using the General Linear Model (GLM) procedure of (SAS, 2008). Significant differences between means were compared using the Duncan's Multiple Range Test of the same GLM.

\section{Result and Discussion}

The result of the molecular analysis of fungi isolate carried out at Bioscience Research Laboratory at the International Institute of Tropical Agriculture (IITA), Ibadan is as shown in Table 1.

Table 1: Isolate Annotation

\begin{tabular}{ccccc}
\hline $\begin{array}{c}\text { Isolate } \\
\text { Annotation }\end{array}$ & $\begin{array}{c}\text { Putative Organism } \\
\text { Identity }\end{array}$ & $\begin{array}{c}\text { Number of } \\
\text { bases/Query Cover }\end{array}$ & $\begin{array}{c}\text { Probable } \\
\text { Identity (\%) }\end{array}$ & $\begin{array}{c}\text { Accession } \\
\text { Number }\end{array}$ \\
\hline Fungal Isolate & $\begin{array}{c}\text { Aspergillus } \\
\text { tubingensis }\end{array}$ & $580(85 \%)$ & $98.44 \%$ & MT312764.1 \\
& & &
\end{tabular}

Aspergillus tubingensis strain G36 small subunit ribosomal RNA gene, partial sequence; internal transcribed spacer 1 and 5.8S ribosomal RNA gene, complete sequence; and internal transcribed spacer 2, partial sequence 
Results of optimization of xylanase production using various agro-waste residues as substrates/ carbon sources for the xylanase production by Aspergillus tubingensis are shown in Fig. 1 to Fig. 4. Notable environmental and fermentation factors that influence metabolism-mediated production yields include $\mathrm{pH}$, temperature, aeration, agitation, carbon and nitrogen sources, metal ion requirement, incubation time, initial inoculum size, Ch et al. (2008). Among the lignocellulosic materials tested as carbon source, Corn cobs showed the highest xylanase activity $(111.23 \pm 0.31 \mathrm{U} / \mathrm{g})$ among the four substrates followed by rice husk $(101.19 \pm 0.72 \mathrm{U} / \mathrm{g})$. The cost availability and physicochemical characteristics of substrates were the main factors for the selection of substrates for enzyme production (Delabona et al., 2012).

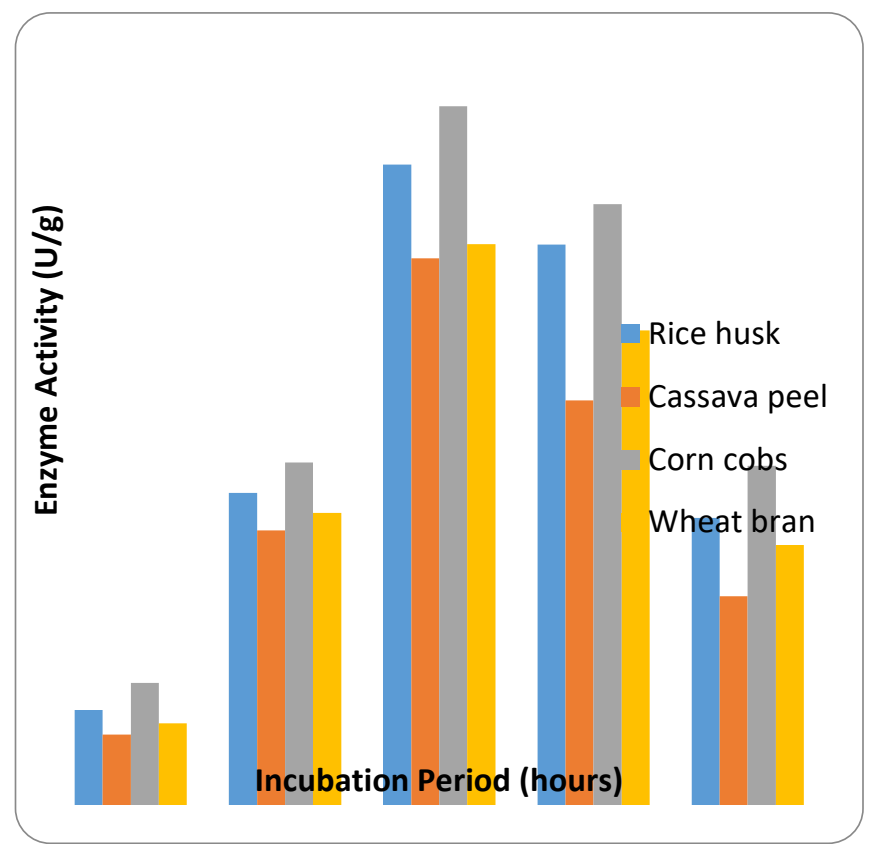

Figure 1: Effect of pH on xylanase production by Aspergillus tubingensis

Effect of $\mathbf{p H}$ on xylanase production by Aspergillus tubingensis

The $\mathrm{pH}$ is an important cultural condition that determines growth rate and influences the level of enzyme production by microorganisms. The best xylanase activity $(107.97 \pm 0.90 \mathrm{U} / \mathrm{g})$ was obtained when the $\mathrm{pH}$ value was at 6.0 on Corn cobs as shown in Fig. 1. The highest yield of xylanase for other substrates was obtained at $\mathrm{pH}$ value of 6.0 for Rice husk $(95.61 \pm 0.98 \mathrm{U} / \mathrm{g})$, Wheat bran
$(89.53 \pm 0.72 \mathrm{U} / \mathrm{g})$ and Cassava peel $(85.40 \pm 0.50$ $\mathrm{U} / \mathrm{g})$. The lowest xylanase activity was obtained when the $\mathrm{pH}$ value was 10.0 for all substrates; Corn cobs $(23.68 \pm 0.58 \mathrm{U} / \mathrm{g})$, Rice husk (20.80 \pm 0.67 $\mathrm{U} / \mathrm{g})$, Wheat bran $(18.72 \pm 0.88 \mathrm{U} / \mathrm{g})$ and Cassava peel $(15.27 \pm 1.47 \mathrm{U} / \mathrm{g})$. Hence, the optimal $\mathrm{pH}$ value observed was $\mathrm{pH}$ 6.0. The result obtained was in accordance with the result of Bhushan et al. (2012), who reported a $\mathrm{pH}$ of 6.0 for maximum xylanase production by Aspergillus flavus MTCC9390 using wheat straw as substrate and $25 \mathrm{~mL}$ of Mandels and Sternburg's (MS) medium. Production of enzyme at higher or lower $\mathrm{pH}$ decreases due to inactivation of enzymatic system. Ionic characters of amino and carboxylic group are also influenced by difference in $\mathrm{pH}$ which affects the catalytic activity of enzymes (Agnihotri et al., 2010). Microorganism holds a range of $\mathrm{pH}$ for its growth and activity with an optimum values and between these ranges, the initial $\mathrm{pH}$ influences enzymatic system and the transport of enzyme across cell membrane (Poorna et al., 2007; Mohana et al., 2008).

\section{Effect of Incubation Period on Xylanase Production by Aspergillus tubingensis}

The results in Fig. 2 showed that xylanase activities commenced after the first day $(24 \mathrm{~h})$ of incubation at $30^{\circ} \mathrm{C}$. A significant decrease of xylanase activities were noticed after day 3 (72 h). The highest xylanase activity was obtained at 72 hours, for all substrates. Corn cobs showed the highest yield of xylanase activity $(111.23 \pm 0.31$ $\mathrm{U} / \mathrm{g})$, followed by Rice husk (101.91 $\pm 0.72 \mathrm{U} / \mathrm{g})$, Wheat bran $(89.30 \pm 1.16 \mathrm{U} / \mathrm{g})$ and Cassava peel $(87.03 \pm 0.57 \mathrm{U} / \mathrm{g})$. The lowest yield was obtained at 24 hours for all substrates; Corn cobs $(19.44 \pm 0.27$ $\mathrm{U} / \mathrm{g})$, Rice husk $(15.17 \pm 0.39 \mathrm{U} / \mathrm{g})$, Wheat bran $(13.01 \pm 1.87 \mathrm{U} / \mathrm{g})$ and Cassava peel $(11.24 \pm 0.71$ $\mathrm{U} / \mathrm{g})$. The middle incubation period for optimum production of xylanase tend to reduce the risk of contamination and decrease the cost of xylanase production. This is in accordance with the report of Fadel et al. (2001). A crude endo-xylanase produced by BCC14405 was optimized by cultivating on medium containing wheat bran, rice bran and soy meal supplement was reported to have produced $89.5 \mathrm{IU} / \mathrm{ml}$ Reis et al. (2003). 
Optimization of culture condition for xylanase production from Aspergillus fumigatus strain MA28 was carried out by growing them on different substrates like wheat bran, rice bran, sawdust, rice straw, powdered corncob, maize bran, wheat flour mill waste or cotton seed cake as the carbon source (Bajaj and Abbass, 2011).

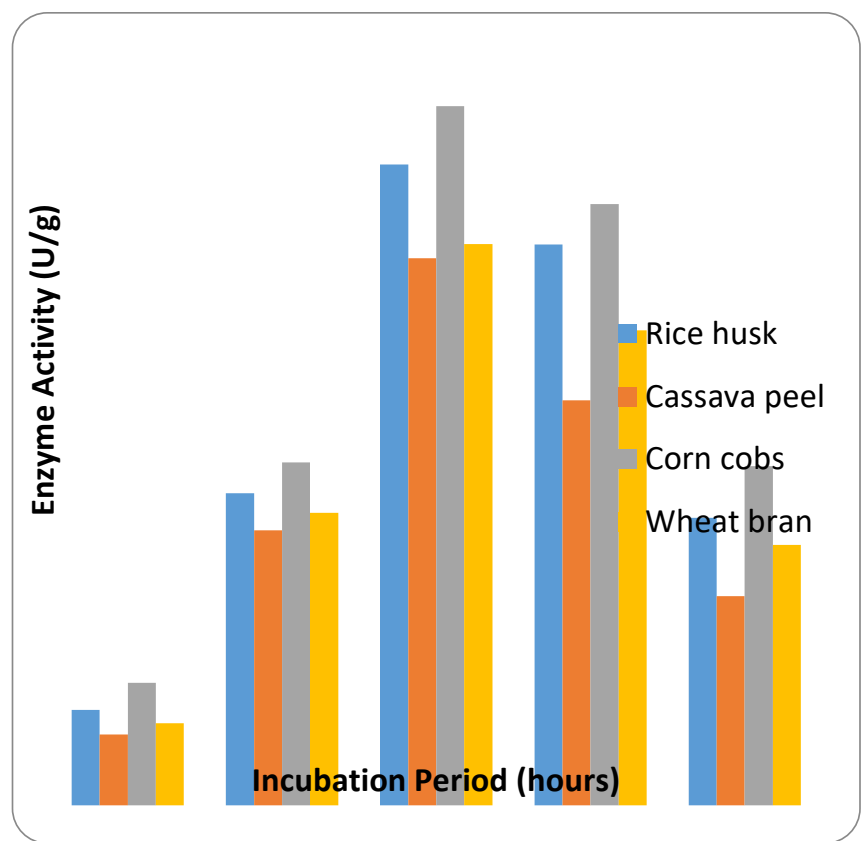

Figure 2: Effect of Incubation period on xylanase production by Aspergillus tubingensis

Effect of Temperature on xylanase production by Aspergillus tubingensis

The highest xylanase activity was obtained when the temperature was at $30^{\circ} \mathrm{C}$ for all substrates as shown in Figure 3 . At $30^{\circ} \mathrm{C}$, Corn cobs showed the highest yield of xylanase activity $(44.26 \pm 0.93$ $\mathrm{U} / \mathrm{g})$, followed by Rice husk $(39.16 \pm 1.20 \mathrm{U} / \mathrm{g})$, Wheat bran $(36.83 \pm 1.19 \mathrm{U} / \mathrm{g})$ and Cassava peel $(33.52 \pm 0.29 \mathrm{U} / \mathrm{g})$. The lowest yield was obtained at higher temperature of $50^{\circ} \mathrm{C}$ for all substrates; Corn cobs $(14.85 \pm 0.70 \mathrm{U} / \mathrm{g})$, Rice husk $(12.78 \pm 0.10$ $\mathrm{U} / \mathrm{g})$, Wheat bran $(11.34 \pm 0.85 \mathrm{U} / \mathrm{g})$ and Cassava peel $(10.37 \pm 0.84 \mathrm{U} / \mathrm{g})$. According to Seyis \& Aksoz (2005), the fermentation temperature has vital effect on the level of xylanase production because of its important role in the metabolic activities of microorganisms. The optimum temperature was recorded for xylanase production at $30^{\circ} \mathrm{C}$ by Aspergillus tubingensis. Increased or decreased temperature from $30^{\circ} \mathrm{C}$ resulted to decrease of xylanase production. At lower temperature, xylanase production decrease because of lower transport of substrates through the cell membrane (Pal \& Khanum, 2010). Higher temperature results to poor growth because of thermal denaturation of enzymes for metabolic pathways, that shows the higher maintenance energy for cellular growth and lower the production of metabolites (Shah \& Madamwar, 2005). The enzyme production gradually decreased with increase in temperature. This result was similar to the previous report that optimum temperature was recorded at $30^{\circ} \mathrm{C}$ from the strains of Trichoderma sp. (Pang et al., 2006) and Aspergillus niger (Simoes et al., 2009). It was reported that optimum temperature for enzyme production also depends on strain variation of the microorganisms (Gautam et al., 2010). This result is comparable to earlier report that maximum xylanase production (2701 U/gds) was observed by Aspergillus foetidus at $30^{\circ} \mathrm{C}$ under SSF conditions after 4 days of incubation (Shah \& Madamwar, 2005).

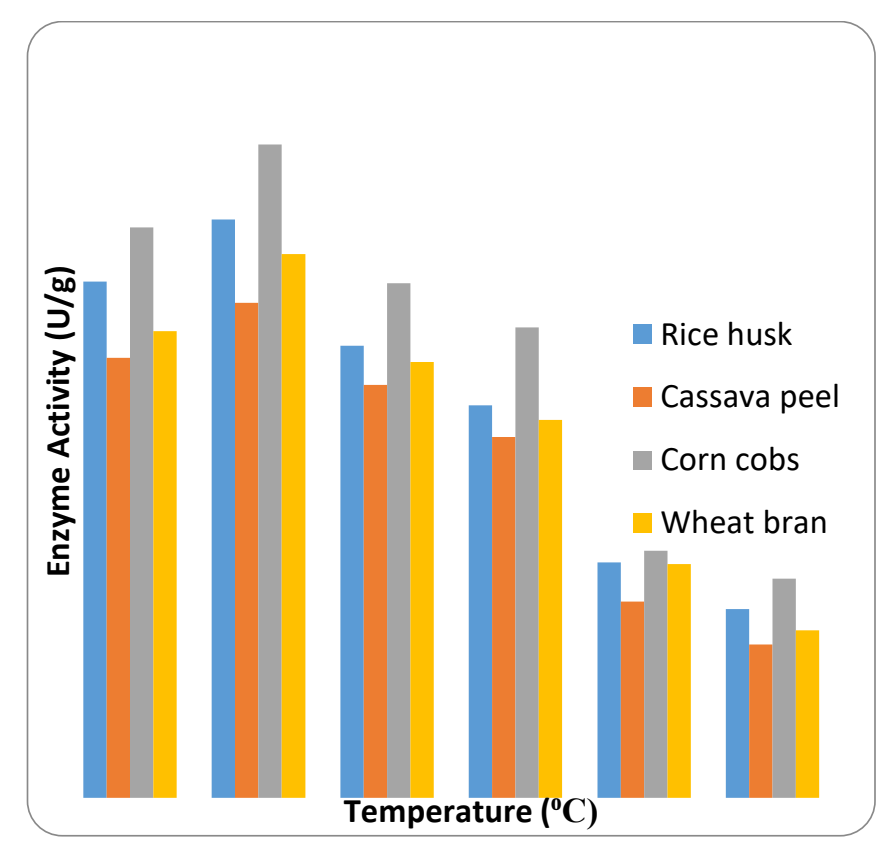

Figure 3: Effect of Temperature on xylanase production by Aspergillus tubingensis

\section{Effect of Substrate Concentration on Xylanase Production by Aspergillus tubingensis}

The results in Fig. 4 showed that Corncob produced the highest yield of xylanase activity at ratio 1:3 (45.68 $\pm 0.31 \mathrm{U} / \mathrm{g})$, followed by Rice husk 
$(40.13 \pm 0.23 \mathrm{U} / \mathrm{g})$, Wheat bran $(39.66 \pm 0.36 \mathrm{U} / \mathrm{g})$ and Cassava peel $(37.09 \pm 1.57 \mathrm{U} / \mathrm{g})$. The lowest yield was obtained at ratio 1:5 $(18.97 \pm 1.28 \mathrm{U} / \mathrm{g})$ for Corn cobs, Rice husk $(15.17 \pm 0.39 \mathrm{U} / \mathrm{g})$ at ratio $1: 1$, Wheat bran $(13.01 \pm 1.87 \mathrm{U} / \mathrm{g})$ at ratio $1: 1$ and Cassava peel $(11.24 \pm 0.71 \mathrm{U} / \mathrm{g})$ at ratio $1: 1$. It was noted that when the concentration of each carbon source was increased, the enzyme activity level in the culture medium decreased. This could be as a result of the higher levels of substrates that eventually reduced the culture agitation resulting in a reduced accessibility of the fungus to the substrates, and hence, a lower observed enzymatic activity (Nichawee et al., 2011). This result was in accordance with the report of Pal and Khanum, (2010) that Corncob, wheat bran and xylan are known to be good microorganism xylanase inducers. It was reported that optimum level of substrate concentration depends on substrate type, substrate size, organism and test enzyme (Fadel, 2000). The decline of xylanase activity at lower substrate levels (1:1 and 1:2) may also be associated with shallow depth, high moisture content and high inoculum size. The findings of this study are in accordance with the findings of (Kumar and Satyanarayana, 2004) and (Fadel et al., 2001).

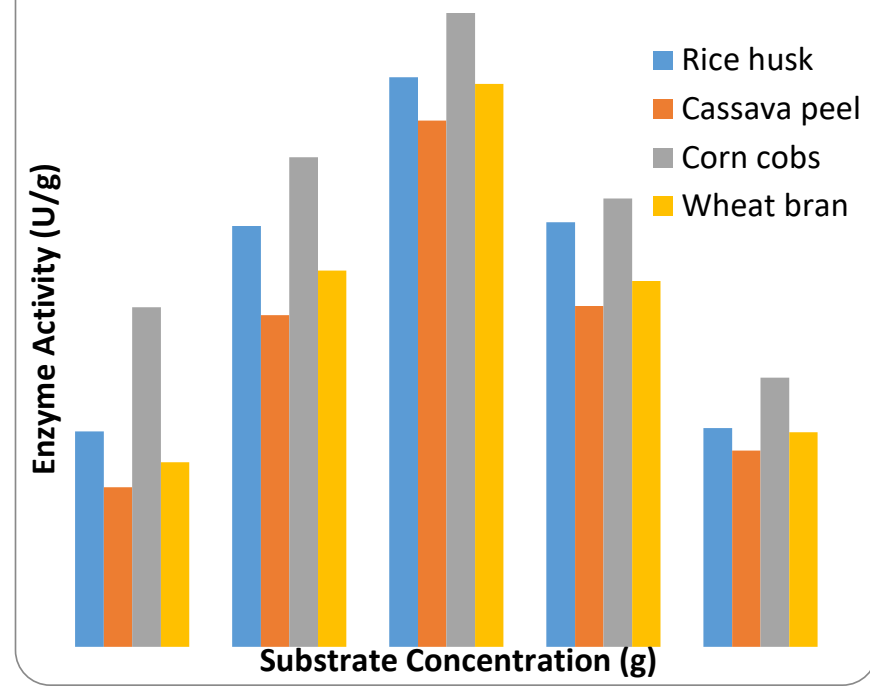

Figure 4: Effect of substrate concentration on xylanase production by Aspergillus tubingensis

However, the decrease in xylanase activity at higher level (1:5) may be associated with high substrate depth, low moisture content, lower inoculums size, reduction of substrate swelling and nutrient diffusion. These results are comparable to those obtained by (Lonsane et al., 1985) and (Fadel et al., 2001).

\section{Conclusion}

Fungi isolate was isolated and identified as Aspergillus tubingensis following the culture technique and molecular identification.

Agricultural wastes such as cassava peels, corn cobs, rice husk and wheat bran could be used as substrates for the production of xylanase. Result showed that substrate with the highest yield of xylanase activity is Corn cobs.

The optimum growth conditions for the production of xylanase by Aspergillus tubingensis were: $\mathrm{pH}$ 6.0, incubation period of 72 hours, temperature of $30^{\circ} \mathrm{C}$ and substrate concentration of $1: 3$ ( $4 \mathrm{~g}$ of substrate per $12 \mathrm{ml}$ of fermentation medium). The optimization of cultural conditions has shown to increase the growth rate of organism and xylanase activity.

\section{Acknowledgements}

The authors are thankful to the Department of Microbiology, Faculty of Life Sciences, University of Ilorin for making the laboratory facilities available.

\section{References}

Aberkane, A., Cuenca-Estrella, M., Gomez-Lopez, A., Petrikkou, E., Mellado, E., Monzon, A., \& Rodriguez-Tudela, J. L. (2002). Comparative evaluation of two different methods of inoculum preparation for antifungal susceptibility testing of filamentous fungi. Journal of Antimicrobial Chemotherapy, 50(5), 719-722.

Agnihotri, S., Dutt, D \& Tyagi, C.H. (2010). Complete characterization of Baggase of early species of Saccharum officinerum-co 89003 for Pulp and Pulp making. Journal of BioResources, 5(2), 1197-1214.

Ajijolakewu, K.A., Lee, C. K., Abdullah, W.N.W., \& Leh, C.P. (2017). Enhanced ethanol production from mild alkali-treated oil-palm empty fruit bunches via co-fermentation of glucose and xylose. Renewable Energy, 107, 113-123.

Ajijolakewu, K.A., Leh, C.P., Abdullah, W.N.W., \& Lee, C.K. (2016). Assessment of the Effect of 
Easily- metabolised Carbon Supplements on Xylanase Production by Newly Isolated Trichoderma asperellum USM SD4 Cultivated on Oil Palm Empty Fruit Bunches. BioResources, 11(4), 9611- 9627.

Bailey, M. J., Biely, P \& Poutanen, K. (1992). Interlaboratory testing of methods for assay of xylanase activity. Journal of Biotechnology, 23(3), 257-70.

Bajaj, B. K., \& Abbass, M. (2011). Studies on an alkali-thermostable xylanase from Aspergillus fumigates MA28. 3. Biotech. 1(3): 161-171.

Beauchemin, K. A., Yang, W.Z \& Rode, L.M. (1999). Effects of grain source and enzyme additive on site and extent of nutrient digestion in dairy cows. Journal of Dairy Science, 82, 378-390.

Bhushan, B., Pal, A., Jain, V. (2012). Isolation, screening and optimized production of extracellular xylanase under submerged condition from Aspergillus flavus MTCC 9390. Enzyme Engg. 1(1), 1-6.

Delabona, P., Farinas, C. S., da Silva, M. R., Azzoni, S. F., \& da Cruz Pradella, J. G. (2012). Use of a new Trichoderma harzianum strain isolated from the Amazon rainforest with pretreated sugar cane bagasse for on-site cellulase production. Bioresource Technology, 107, 517-521.

Fadel, M. (2001). High-level xylanase production from sorghum flour by a newly isolate of Trichoderma harzianum cultivated under solid state fermentation. Annals of Microbiology, 51(1), 61-78.

Fadel, M., (2000). Production physiology of cellulases and $\beta$-glucosidase enzymes of

Pang, P. K., Darah, I., Poppe, L., Szakacs, G. \& Ibrahim, C. O. (2006). Xylanase production by local isolate, Trichoderma spp. FETL C3-2 via solid-state fermentation using agricultural wastes as substrates. Malaysian Journal of Microbiology, 2, 7-14.

Poorna, C.A., \& Prema, P (2007). Production of cellulase-free endoxylanase from novel alkalophilic thermotolerant Bacillus pumilus by solid-state fermentation and its application in wastepaper recycling. Bioresource. Technology, 98, 485-490.
Aspergillus niger grown under solid state fermentation conditions. Online Journal of Biological. Science, 1(5), 401-411.

Gautam, S.P., Bundela, P.S., Pandey, A.K., Awasthi, M.K., \& Sarsaiya, S. (2010). Cellulase production by Pseudomonas sp. Isolated from Municipal solid waste compost. International Journal of Academic Research, 2(6).

Kumar, S \& Satyanarayana. (2004). Statistical optimization of thermostable and neutralglucoamylase production by a thermophilic mold Thermomucor indicaeseudaticae in solid -state fermentation. World Journal of Microbiology and Biotechnology, 20, 895-902.

Lonsane, B. K., Ghildyal, N. P., Budiatman, S., \& Ramakrishna, S. V. (1985). Engineering aspects of solid state fermentation. Enzyme and Microbial Technology, 7(6), 258-265.

Mohana, S., Shah, A., Divecha, J., \& Madamwar, D. (2008). Xylanase production by Burkholderia sp. DMAX strain under solid state fermentation using distillery spent wash. Bioresource Technology, 99(16), 7553-7564.

Nichawee, W., Prakitsin, S., Jittra, P., Polkit, S. \& Aphichart, K. (2011). Purification and characterization of a xylanase from the endophytic fungus Alternaria alternata isolated from the Thai medicinal plant, Croton oblongifolius Roxb. African Journal of Microbiology Research 5(31), 5697- 5712.

Pal, A., \& Khanum, F. (2010). Production and extraction optimization of xylanase from Aspergillus niger DFR-5 through solid-statefermentation. Bioresource Technology, 101(19), 7563-9.

Reis, S., Costa, M. A. F., \& Peralta, R. M. (2003). Xylanase production by a wild strain of Aspergillus nidulans. Acta Scientiarum Biological Sciences, 25, 221-225.

Rodriguez-Tudela, J. L., Chryssanthou, E., Petrikkou, E., Mosquera, J., Denning, D.W., \& Cuenca-Estrella, M. (2003). Interlaboratory Evaluation of Hematocytometer Method of Inoculum Preparation for Testing Antifungal Susceptibilities of Filamentous Fungi. Journal of Clinical Microbiology, 41(11), 5236-7. 
SAS Institute. (2008). SAS/STAT Software, Simões, M., Bennett, R.N., \& Rosa, E.A.S. (2009). Release 9.1. SAS Institute, Inc., Cary, NC.

Seyis, I \& Aksoz, N. (2005). Xylanase production from Trichoderma harzianum 1073 D3 with alternative carbon and nitrogen sources. Food Technology and Biotechnology, 43, 37-40.

Shah, A.R., \& Madamwar, D. (2005). Xylanase production by a newly isolated Aspergillus foetidus strain and its characterization. Process Biochemistry, 40(5), 1763-1771

Understanding antimicrobial activities of phytochemicals against multidrug resistant bacteria and biofilms. Natural Product Reports, 26(6), 746-757

Uday, U.S.P., Choudhury, P., Bandyopadhyay, T.K., \& Bhunia, B. (2016). Classification, mode of action and production strategy of xylanase and its application for biofuel production from water hyacinth. International Journal of Biological Macromolecules, 82, 1041-1054 


\section{Appendix}

Table 2: Xylose Standard

\begin{tabular}{ccccc}
\hline $\begin{array}{c}\text { CONCENTRATION } \\
\boldsymbol{\mu m o l} / \mathbf{m l}\end{array}$ & ABS 1 & ABS 2 & ABS 3 & $\begin{array}{c}\text { AVERAGE } \\
\text { ABSORBANCE }\end{array}$ \\
\hline $1: 1(10)$ & 1.857 & 1.868 & 1.863 & 1.863 \\
$1: 1.5(6.7)$ & 1.242 & 1.239 & 1.235 & 1.239 \\
$1: 2(5)$ & 0.938 & 0.925 & 0.934 & 0.932 \\
$1: 3(3.3)$ & 0.514 & 0.531 & 0.509 & 0.518 \\
$1: 5(2)$ & 0.372 & 0.366 & 0.389 & 0.376 \\
\hline
\end{tabular}

Key: ABS-absorbance in triplicate

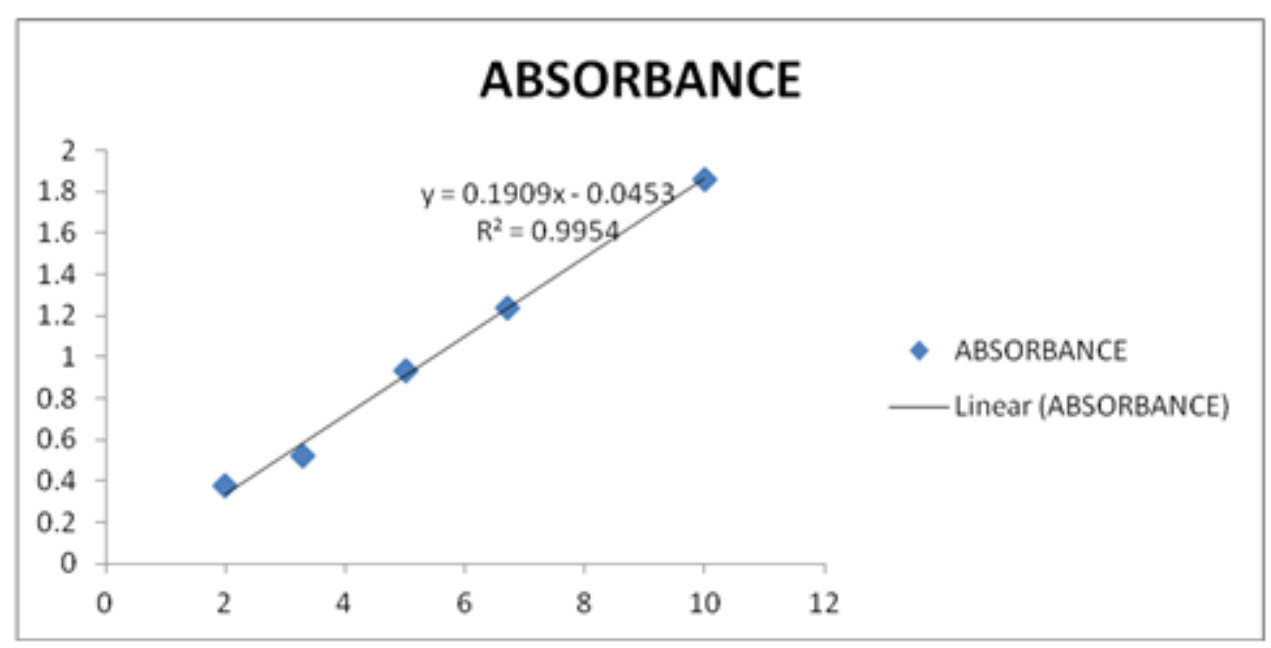

Figure 1: Graph of Absorbance Vs Concentration

Table 3: Xylose Standard

\begin{tabular}{lcccc}
\hline $\begin{array}{l}\text { CONCENTRATION } \\
\mu \mathrm{mol} / \mathrm{ml}\end{array}$ & ABS 1 & ABS 2 & ABS 3 & $\begin{array}{l}\text { AVERAGE } \\
\text { ABSORBANCE }\end{array}$ \\
\hline 10 & 1.584 & 1.572 & 1.578 & 1.578 \\
6.7 & 1.319 & 1.322 & 1.325 & 1.322 \\
5 & 1.217 & 1.203 & 1.208 & 1.209 \\
3.3 & 0.966 & 0.978 & 0.969 & 0.971 \\
2 & 0.771 & 0.722 & 0.785 & 0.759 \\
\hline \multicolumn{5}{c}{ ABS-absorbance in triplicate }
\end{tabular}




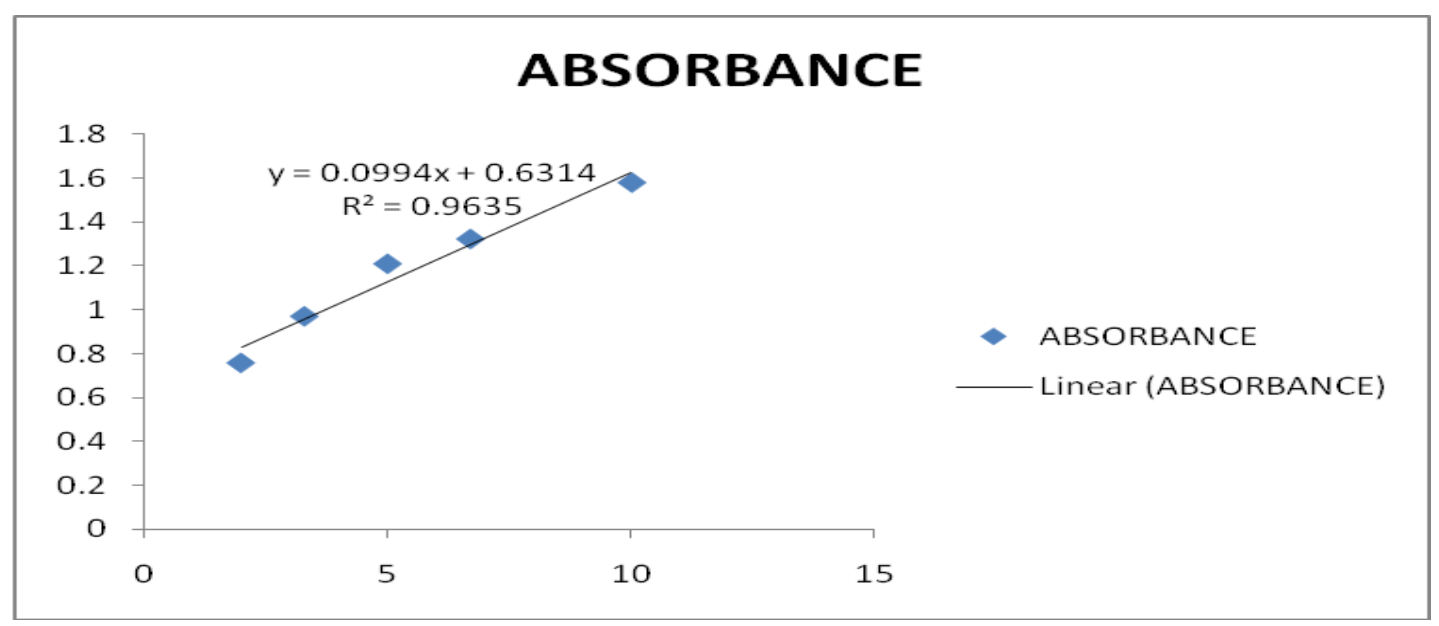

Figure 2: Graph of Absorbance Vs Concentration 